Invitations have been extended on behalf of the President of the United States to the participating countries to be represented by delegates on this occasion. The American Geophysical Union is the American section of the International Union of Geodesy and Geophysics, and its executive committee is the Committee on Geophysics of the National Research Council. The Council is collaborating with the American Geophysical Union as host to the assembly. The last general assembly of the International Union was held at Edinburgh, Scotland, in September 1936. The thirty-five nations at present adhering to the International Union are : Argentina, Belgium, Brazil, Bulgaria, Canada, Colombia, Chile, Czechoslovakia, Denmark, Egypt, Finland, France, Germany, Great Britain, Greece, Holland, Hungary, Indo-China, Italy, Japan, Morocco, Mexico, New Zealand, Norway, Peru, Poland, Portugal, Rumania, Siam, Spain, Sweden, Switzerland, Union of Soviet Socialist Republics, United States, and Yugoslavia.

\section{Another Large Sunspot}

THe giant sunspot which crossed the sun's disk between October 5 and 18 broke up before its return, due at the eastern limb on November 2. Meanwhile, another large spot had formed in solar longitude $273^{\circ}$ and in latitude $9^{\circ}$ south. This spot came round the limb on November 4, though it was not completely seen until the following day, when its area was 2000 millionths of the sun's hemisphere. The time of central meridian passage was November 10.8 U.T.; its date of disappearance around the western limb will be November 17 .

\section{Announcements}

Dr. W. D. LANG, keeper of the Department of Geology of the British Museum (Natural History), is to retire on December 29. The principal trustees of the Museum have appointed Mr. W. N. Edwards, deputy keeper of the Department, to succeed Dr. Lang. Mr. Edwards was born in 1890 and was a scholar of Christ's College, Cambridge. He entered the British Museum (Natural History) as an assistant in the Department of Geology in 1913 and became deputy keeper in 1931. He is an authority on fossil plants and has travelled extensively.

DR. T. S. WHEELER, principal of the Royal Institute of Science, Bombay, has left India and will shortly take up his new appointment as State Chemist, Eire.

Mr. J. Wickham Murray, secretary of the Asso. ciation of Teachers in Technical Institutions, has been appointed an official for higher education by the executive of the National Union of Teachers.

Ar the anniversary meeting of the Mineralogical Society on November 3, the following were elected officers: President and Editor of the Journal, Dr. L. J. Spencer ; Vice-Presidents, Prof. C. E. Tilley and Lieut.-Colonel W. Campbell Smith; Treasurer,
F. N. Ashcroft ; General Secretary, G. F. Claringbull ; Foreign Secretary, Sir Thomas Holland.

A symposium on "Gas Temperature Measurement" will be held by the Institute of Fuel in the lecture theatre of the Institution of Electrical Engineers, Savoy Place, Victoria Embankment, W.C.2, on December 2. It will commence at 10.30. Further information can be obtained from the Secretary, Institute of Fuel, 53 Victoria Street, London, S.W.1.

The Royal Sanitary Institute Congress of 1939 will be held at Scarborough on July 3-8 and the Congress of 1940 at Torquay on July 1-6. Further information can be obtained from the Secretary of the Institute, 90 Buckingham Palace Road, London, S.W.1.

A Fourxh Farming Conference will be held at Oxford under the joint auspices of the School of Rural Economy, the Agricultural Economics Research Institute and the Institute for Research in Agricultural Engineering of the University of Oxford on January 3-5, 1939. Further information can be obtained from the Conference Secretary, 10 Parks Road, Oxford.

THE Far Eastern Association of Tropical Medicine will hold its tenth Congress at Hanoï, Tonkin, on November 24-30, when discussions will be held on feeding in deficiency diseases, cholera, malaria, plague, tuberculosis, venereal disease, surgery, diseases common to man and animals, parasitology and local anthropological characteristics.

Tre next International Congress of Surgery will be held in 1941 at Stockholm under the presidency of Dr. Leopold Mayer.

THE Congress of Comparative Pathology will be held in Rome on May 15-20, 1939, under the presidency of Prof. Rondoni, director of the Cancer Institute at the University of Milan. The following subjects will be discussed: ultra-virus diseases; heredity in pathology; the association of antigens. and their function; regressive processes in plants The secretary of the Congress is Prof. Zavagli at Consiglio Nazionale delle Ricerche, Piazzale delle Scienze, Rome, from whom further information can be obtained.

The Home Secretary proposes to make regulations under the Factory Act 1937 extending the provisions of Section 66 to compressed air illness. Copies of the draft regulations may be ordered through any bookseller from H.M. Stationery Office.

The Pasteur Institute of Algiers, of which Dr. Edmond Sergent is director, has been authorized by the French Government to sell a serum against scorpions prepared from immunized horses.

Erratum. In Nature, November 5, p. 843, "Origin of the Solar System"; last line of first paragraph, for "internal" read "external". 